\title{
Adult-Onset Ataxia With Neuropathy and White Matter Abnormalities Due to a Novel SAMD9L Variant
}

Martin Paucar, MD, PhD,* Bianca Tesi, MD, PhD, * Saeed Eshtad, PhD, Caroline Eriksson, MSc, Farouk Hashim, MD, Daniel Nilsson, PhD, Kaveh Pourhamidi, MD, PhD, Eva Hellström-Lindberg, MD, PhD, Yenan T. Bryceson, PhD, and Per Svenningsson, MD, PhD

Neurol Genet 2021;7:e628. doi:10.1212/NXG.0000000000000628

Variants in tumor suppressor genes and in genes encoding DNA repairing proteins are associated with syndromes conferring neurologic features and increased risk for malignancy. The best example for these conditions is ataxia-telangiectasia (AT). A more rare and recent disease is an ataxia-pancytopenia syndrome (ATXPC) associated with heterozygous gain-of-function variants in the tumor suppressor gene SAMD9L (MIM 159550). Here, we describe a patient with a complex cerebellar syndrome associated with a novel SAMD9L pathogenic variant.

\section{Case Presentation}

A 54-year-old Swedish man presented with progressive gait difficulties, impaired coordination, dizziness, falls, slurred speech, and urinary urgency. Age at onset was 42 years. Later, recurrent episodes with profuse sweating and crawling in both calves started to occur. There was no family history of movement disorders or other neurologic diseases. His mother died of glioblastoma at age 65 years and his father of cardiac disease. His medical history was unremarkable. Examination revealed dysmetria, inability to perform tandem gait, reduced arm swing, dysarthria, positive Romberg test, conjunctival telangiectasias, nystagmus, and pes cavus (Video 1). Reflexes were brisk, with mild spasticity in the legs. Muscle tone in the arms, sensation to pinprick, strength, and proprioception were normal, and the Babinski sign was absent, but vibration was reduced in both malleoli. At age 50 years, his Scale for the Assessment and Rating of Ataxia score was $10 \mathrm{p}$, and 3 years later, it was $11.5 \mathrm{p}$ (range 0-40 points). ${ }^{1}$ There were no signs of orthostatism, and the patient denied gastrointestinal symptoms. ENeG and quantitative sensory testing demonstrated a demyelinating sensorimotor neuropathy and elevated thresholds for heat and cold. EMG revealed chronic mild neurogenic abnormalities in the distal leg and arm muscles with no signs of active denervation, whereas motor evoked potential yielded normal findings. A mild symmetric sensorineural hearing loss was found, but the patient does not require hearing aids. Ophthalmologic evaluation, which included optical coherence tomography and eye-bottom examination, demonstrated presbyopia but no evidence of retinal pathology.

Brain MRI with contrast demonstrated marked cerebellar atrophy and confluent periventricular hyperintensities. Additional hyperintensities were found in deep white matter regions that included the corpus callosum's left trunk. There were multiple cysts ranging in size between 1.5 and $3 \mathrm{~mm}$ within the hyperintensities and increased T2-weighted signal in the putamen, caudate, and dentate nuclei (Figure). A CT scan ruled out calcifications in the brain. A large
Correspondence

Dr. Paucar

martin.paucar-arce@sll.se
MORE ONLINE

Video

*These authors contributed equally to this work.

From the Department of Clinical Neuroscience (M.P., F.H., K.P., P.S.), Karolinska Institutet; Department of Neurology (M.P., P.S.); Department of Clinical Genetics (B.T., D.N.), Karolinska University Hospital; Department of Molecular Medicine and Surgery (B.T., D.N.); Center for Hematology and Regenerative Medicine (S.E., C.E., E.H.-L.), Department of Medicine, Karolinska Institutet; Department of Pediatric Radiology (F.H.); Department of Neurophysiology (K.P.); Department of Hematology (E.H.-L., Y.T.B.); Department of Immunology and Transfusion Medicine (Y.T.B.), Karolinska University Hospital, Stockholm, Sweden; and Broegelmann Laboratory (Y.T.B.), Department of Clinical Sciences, University of Bergen, Norway.

Go to Neurology.org/NG for full disclosures. Funding information is provided at the end of the article.

The Article Processing charge was funded by the authors.

This is an open access article distributed under the terms of the Creative Commons Attribution-NonCommercial-NoDerivatives License 4.0 (CC BY-NC-ND), which permits downloading and sharing the work provided it is properly cited. The work cannot be changed in any way or used commercially without permission from the journal. 


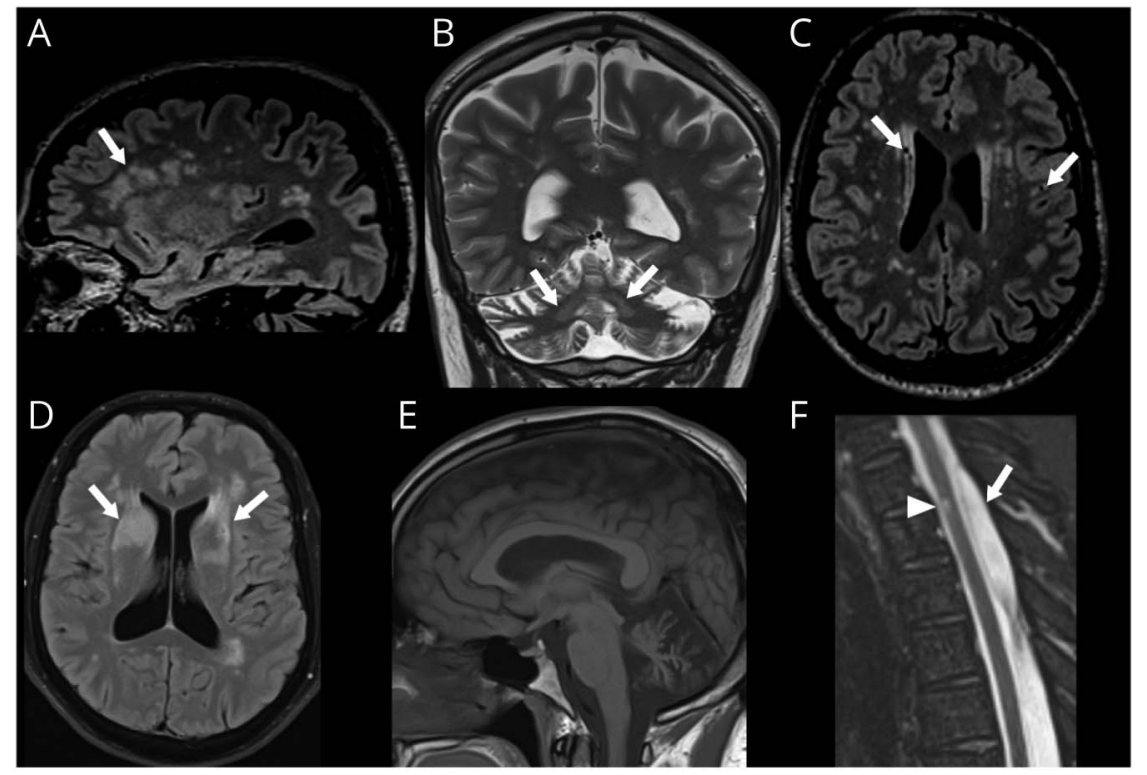

(A) 3D T2 weighted FLAIR sections demonstrate partially confluent periventricular hyperintensities. Hyperintensities are also seen in other white matter locations with frontal predominance in a parasagittal section (arrow). (B) Bilateral hyperintensities are shown in the dentate nuclei in a coronal section (arrows). (C) The axial section demonstrates multiple cysts within the periventricular hyperintensities (arrows). Axial T2 turbo spin echo FLAIR section displays an increased signal in the putamen and caudate nucleus bilaterally ( $D$, arrows). Severe cerebellar atrophy is shown on this parasagittal $\mathrm{T} 1$ turbo spin echo section (E). T2 turbo inversion recovery magnitude section demonstrates a large posterior arachnoidal cyst with dural ectasia extending from Th1 to $L 2$ levels ( $F$, arrow) and an anterior lesion with possible slight loss of volume at the Th1 level (Arrow head). FLAIR = fluid-attenuated inversion recovery.

posterior arachnoidal cyst with dural ectasia was found extending from Th1 to L2 levels which prevented a lumbar puncture. A more subtle dural ectasia was found at $\mathrm{C} 1-\mathrm{C} 2$ and sacral levels but no evidence of spinal cord atrophy. The neuroimaging abnormalities remain unchanged 3 years later. Cobalamin was mildly reduced, but extensive laboratory tests were normal (eTable 1, links.lww.com/NXG/A481). Pathologic nucleotide expansions were ruled out. Blood-derived DNA was investigated by whole genome sequencing (WGS). WGS analysis revealed a heterozygous variant in SAMD9L (NM_152703, c.2915T>C p.Ile972Thr), encoding the sterile alpha motif domain containing 9-like protein, present in 19 of 38 sequencing reads. A second variant in SAMDL9L, c. 3229 C $>$ T p.Arg1077*, was present in 6 out of 32 reads. Both variants were absent in the gnomAD database. Somatic reversion in hematopoietic cells, by uniparental disomy or cis loss-of-function mutations, can resolve the cytopenias otherwise associated with $\mathrm{ATXPC}^{2, \mathrm{e} 1}$ ). The patient had a normal complete blood count. Bone marrow aspiration demonstrated normal cellularity, no dysplastic features, and no evidence of acquired mutations indicative of a myelodysplastic syndrome (targeted sequencing by the TruSight panel). Furthermore, the karyotype was normal, and fluorescence in situ hybridization analysis showed no evidence for monosomy 7 or $\operatorname{del}(7 q)$. Deep sequencing of $S A M D 9 L$ in blood, bone-marrow, as well as fibroblast-derived DNA from a skin biopsy confirmed the germline origin of the $S A M D 9 L$ c. $2915 \mathrm{~T}>\mathrm{C}$ variant, whereas the SAMD9L c.3229C>T variant as well as another c.3456_3458del (p.Leu1153del) were detected exclusively in blood and bone-marrow from the patient (eTable 2, links.lww.com/NXG/A482). Segregation studies for the germline variant were not possible because both parents were deceased. Stable HEK-293T cell transfectants with inducible expression of SAMD9L variants were generated. $S A M D 9 L$ wild-type and patientderived variants were readily expressed on induction with doxycycline (eFigure 1A, links.lww.com/NXG/A480). Cellular assays demonstrated that expression of the novel germline SAMD9L c.2915T>Cp.Ile972Thr variant diminished cell proliferation to similar levels as the previously reported SAMD9L p.His880Gln gain-of-function variant (eFigure 1, B and C). Although several truncating SAMD9L gain-offunction variants around amino acids $876-889$ have been described, ${ }^{\mathrm{e} 2}$ the SAMD9L c.3229C $>\mathrm{T}$ p.Arg $1077^{*}$ truncation did not inhibit cell proliferation (eFigure 1C). In other patients, revertant truncations have been positioned at the $\mathrm{N}$-terminus of disease-causing variants. Notably, a construct containing both the disease-causing SAMD9L c.2915T >C p.Ile972Thr and somatic c. $3229 \mathrm{C}>\mathrm{T}$ p.Arg $1077^{*}$ variants did not inhibit cell proliferation, revealing that the revertant mutation alleviated in cis the pathogenic variant.

\section{Discussion}

The presence of revertant mosaicism at high variant allele frequency explains the lack of hematologic phenotype in the patient, indicating that the $\mathrm{C}$-terminus is required for the pathology of the SAMD9L c.2915T >C p.Ile972Thr germline variant. In the original publications delineating ATXPC, most patients displayed cerebellar features. ${ }^{3,4}$ However, in subsequent articles, only few patients, most diagnosed as children, with hematologic abnormalities displayed ataxia or neuropathy $(\sim 14 \%)$. 5, ${ }^{5, \mathrm{e} 1, \mathrm{e} 3, \mathrm{e} 4, \mathrm{e} 5, \mathrm{e} 6}$ The absence of family history in this case might be due to the germline $S A M D 9 L$ variant c.2915T $>$ C being de novo or to reduced penetrance and variable expressivity of neurologic and hematologic signs. ${ }^{\mathrm{el}, \mathrm{e} 7}$ 
The growing spectrum of ATXPC includes white matter abnormalities. ${ }^{2-8}$ Cysts or enlarged perivascular spaces have been reported in ATXPC, ${ }^{6,7}$ while dural ectasia along with spinal cord atrophy has been reported only once. ${ }^{7}$ Age at onset, the presence and types of neuropathy, and pyramidal signs $^{4,7,8}$ are variable. In a few instances, telangiectasias retinal thinning and alveolar proteinosis occur in patients with SAMD9L variants. ${ }^{2,8, e 8}$ Age at onset, phenotype, and slow rate of progression in our case are striking similar to what is seen in variant ataxia-telangiectasia (vA-T). However, the absence of systemic features (immunodeficiency, pulmonary symptoms, endocrinological abnormalities, and intellectual disability) and the type of underlying polyneuropathy differentiate ATXPC from vA-T. Prognosis in ATXPC relies on monitoring for and treating the hematologic abnormalities; thus, a regular follow-up with a hematologist is warranted.

The SAMD9L gene product is an interferon-regulated tumor suppressor, with an important role in the regulation of protein synthesis. ${ }^{\text {e-e11 }}$ When SAMD9L variants are identified in blood, genetic studies in other tissues are needed to distinguish germline from revertant variants. Our case illustrates the importance of C-terminal truncations for disrupting/reversing pathogenic SAMD9L variants. The mechanism of neurologic dysfunction in ATXPC remains to be understood. In addition, the unknown is whether revertant mosaicism takes place in the brain and might explain variable expressivity.

\section{Acknowledgment}

The authors are grateful to the patient for his kind participation and Cecilia Bungerfeldt for referring the patient and thank Mikael Altun for providing a HA-tagged pENTR4 vector. The authors also acknowledge the support from the Clinical Genomics Stockholm facility at Science for Life Laboratory in library preparation, sequencing, and subsequent bioinformatic analysis.

\section{Study Funding}

M. Paucar obtained funding from Region Stockholm and NeuroSweden. B. Tesi and P. Svenningsson have obtained funding from Region Stockholm. S. Eshtad was supported by a postdoctoral grant from the Swedish Children's Cancer Foundation. Research was supported by grants from the Swedish Children's Cancer Foundation, Cancer Foundation, and Knut and Alice Wallenberg Foundation to Y. Bryceson.

\section{Disclosure}

The authors report no disclosures. Go to Neurology.org/NG for full disclosures.

\section{Publication History}

Received by Neurology: Genetics April 28, 2021. Accepted in final form August 24, 2021.

\section{Appendix Authors}

\begin{tabular}{|c|c|c|}
\hline Name & Location & Contribution \\
\hline $\begin{array}{l}\text { Martin Paucar, } \\
\text { MD, PhD }\end{array}$ & $\begin{array}{l}\text { Karolinska University } \\
\text { Hospital and Karolinska } \\
\text { Institutet, Stockholm, } \\
\text { Sweden }\end{array}$ & $\begin{array}{l}\text { Patient care and } \\
\text { investigation, study concept } \\
\text { and planning, analysis and } \\
\text { interpretation of clinical data, } \\
\text { and writing the first draft }\end{array}$ \\
\hline $\begin{array}{l}\text { Bianca Tesi, } \\
\text { MD, PhD }\end{array}$ & $\begin{array}{l}\text { Karolinska University } \\
\text { Hospital and Karolinska } \\
\text { Institutet, Stockholm, } \\
\text { Sweden }\end{array}$ & $\begin{array}{l}\text { Study concept and } \\
\text { planning, analysis and } \\
\text { interpretation of genetic } \\
\text { data and mosaicism, and } \\
\text { writing a revised draft }\end{array}$ \\
\hline $\begin{array}{l}\text { Saeed Eshtad, } \\
\text { PhD }\end{array}$ & $\begin{array}{l}\text { Karolinska Institutet, } \\
\text { Stockholm, Sweden }\end{array}$ & $\begin{array}{l}\text { Experiment with } \\
\text { transfected cells, Western } \\
\text { blots for } S A M D 9 L \text {, and } \\
\text { editing of the article }\end{array}$ \\
\hline $\begin{array}{l}\text { Caroline } \\
\text { Eriksson, MSc }\end{array}$ & $\begin{array}{l}\text { Karolinska University } \\
\text { Hospital, Stockholm, } \\
\text { Sweden }\end{array}$ & $\begin{array}{l}\text { Experiment with } \\
\text { transfected cells, Western } \\
\text { blots for } S A M D 9 L \text {, and } \\
\text { editing of the article }\end{array}$ \\
\hline $\begin{array}{l}\text { Farouk } \\
\text { Hashim, MD }\end{array}$ & $\begin{array}{l}\text { Karolinska Institutet and } \\
\text { Karolinska University } \\
\text { Hospital, Stockholm, Sweden }\end{array}$ & $\begin{array}{l}\text { Interpretation of } \\
\text { neuroimaging data and } \\
\text { editing of the article }\end{array}$ \\
\hline $\begin{array}{l}\text { Daniel Nilsson, } \\
\text { PhD }\end{array}$ & $\begin{array}{l}\text { Karolinska Institutet and } \\
\text { Karolinska University } \\
\text { Hospital, Stockholm, Sweden }\end{array}$ & $\begin{array}{l}\text { Interpretation of genetic } \\
\text { data and editing of the } \\
\text { article }\end{array}$ \\
\hline $\begin{array}{l}\text { Kaveh } \\
\text { Pourhamidi, } \\
\text { MD, PhD }\end{array}$ & $\begin{array}{l}\text { Karolinska Institutet and } \\
\text { Karolinska University } \\
\text { Hospital, Stockholm, } \\
\text { Sweden }\end{array}$ & $\begin{array}{l}\text { Interpretation of } \\
\text { neurophysiologic tests and } \\
\text { editing of the article }\end{array}$ \\
\hline $\begin{array}{l}\text { Eva Hellström- } \\
\text { Lindberg, MD, } \\
\text { PhD }\end{array}$ & $\begin{array}{l}\text { Karolinska Institutet and } \\
\text { Karolinska University } \\
\text { Hospital, Stockholm, } \\
\text { Sweden }\end{array}$ & $\begin{array}{l}\text { Patient care, hematologic } \\
\text { workup, study concept and } \\
\text { planning, and editing of the } \\
\text { article }\end{array}$ \\
\hline $\begin{array}{l}\text { Yenan T. } \\
\text { Bryceson, PhD }\end{array}$ & $\begin{array}{l}\text { Karolinska Institutet and } \\
\text { Karolinska University } \\
\text { Hospital, Stockholm, Sweden } \\
\text { University of Bergen, } \\
\text { Norway }\end{array}$ & $\begin{array}{l}\text { Study concept and planning } \\
\text { for experimental evaluation } \\
\text { of genetic variants, } \\
\text { supervision, and major } \\
\text { editing of the article }\end{array}$ \\
\hline $\begin{array}{l}\text { Per } \\
\text { Svenningsson, } \\
\text { MD, PhD }\end{array}$ & $\begin{array}{l}\text { Karolinska University } \\
\text { Hospital and Karolinska } \\
\text { Institutet, Stockholm, } \\
\text { Sweden }\end{array}$ & $\begin{array}{l}\text { Supervision, analysis and } \\
\text { interpretation of clinical data, } \\
\text { and editing of the article }\end{array}$ \\
\hline
\end{tabular}

\section{References}

1. Schmitz-Hübsch T, du Montcel ST, Baliko L, et al. Scale for the assessment and rating of ataxia: development of a new clinical scale. Neurology. 2006;66(11):1717-1720.

2. van der Knaap MS, Schiffmann R, Mochel F, Wolf NI. Diagnosis, prognosis, and treatment of leukodystrophies. Lancet Neurol. 2019;18(10):962-972.

3. Tesi B, Davidsson J, Voss M, et al. Gain-of-function SAMD9L mutations cause a syndrome of cytopenia, immunodeficiency, MDS, and neurological symptoms. Blood. 2017;129(16):2266-2279.

4. Chen DH, Below JE, Shimamura A, et al. Ataxia-Pancytopenia syndrome is caused by missense mutations in SAMD9L. Am J Hum Genet. 2016;98(6):1146-1158.

5. Bluteau $\mathrm{O}$, Sebert $\mathrm{M}$, Leblanc $\mathrm{T}$, et al. A landscape of germ line mutations in a cohort of inherited bone marrow failure patients. Blood. 2018;131(7):717-732.

6. Cheah JJC, Brown AL, Schreiber AW, et al. A novel germline SAMD9L mutation in a family with ataxia-pancytopenia syndrome and pediatric acute lymphoblastic leukemia. Haematologica. 2019;104(7):e318-e321.

7. Thunström S, Axelsson M. Leukoencephalopathia, demyelinating peripheral neuropathy and dural ectasia explained by a not formerly described de novo mutation in the SAMD9L gene, ends 27 years of investigations—a case report. BMC Neurol. 2019;19(1): 89.

8. Vaughan D, Bogdanova-Mihaylova P, Costello DJ, et al. Ataxia pancytopenia syndrome due to SAMD9L mutation presenting as demyelinating neuropathy. J Peripher Nerv Syst. 2020;25(4):433-437.

eReferences e1-e11 available at: links.lww.com/NXG/A484. 


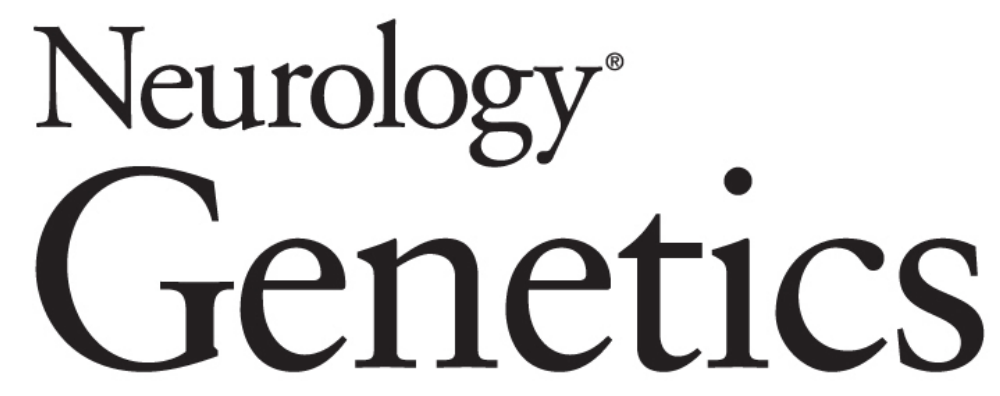

\section{Adult-Onset Ataxia With Neuropathy and White Matter Abnormalities Due to a Novel SAMD9L Variant \\ Martin Paucar, Bianca Tesi, Saeed Eshtad, et al. \\ Neurol Genet 2021;7; \\ DOI 10.1212/NXG.0000000000000628}

This information is current as of October 28, 2021

\section{Updated Information \& Services}

References

Subspecialty Collections

Permissions \& Licensing

Reprints including high resolution figures, can be found at: http://ng.neurology.org/content/7/6/e628.full.html

This article cites 8 articles, 3 of which you can access for free at: http://ng.neurology.org/content/7/6/e628.full.html\#\#ref-list-1

This article, along with others on similar topics, appears in the following collection(s):

All Genetics

http://ng.neurology.org//cgi/collection/all_genetics

Gait disorders/ataxia

http://ng.neurology.org//cgi/collection/gait_disorders_ataxia

Information about reproducing this article in parts (figures,tables) or in its entirety can be found online at:

http://ng.neurology.org/misc/about.xhtml\#permissions

Information about ordering reprints can be found online: http://ng.neurology.org/misc/addir.xhtml\#reprintsus

Neurol Genet is an official journal of the American Academy of Neurology. Published since April 2015, it is an open-access, online-only, continuous publication journal. Copyright Copyright (C) 2021 The Author(s). Published by Wolters Kluwer Health, Inc. on behalf of the American Academy of Neurology.. All rights reserved. Online ISSN: 2376-7839.

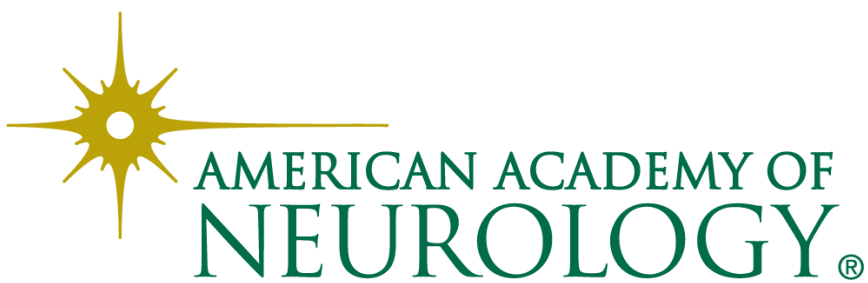

